\title{
Building Contraventions in Tehran and Its Control by the Municipality
}

\author{
Mohammad Hossein Hajialirezalou, Department of Architecture, Shabestar Branch, \\ Islamic Azad University, Shabestar, Iran
}

\begin{abstract}
Most problems of Tehran metropolitan areas are associated with building contraventions. This paper, using descriptive-analytical method, is study of building contraventions in Tehran, Iran and its potential reasons. Discussed factors in non-compliance with building regulations and their quality in Tehran city. Also I argue how Tehran municipality has managed the contraventions of building violations. Given a review of conducted policies and activities related to building control, I concluded that wrong implementation of urban planning in Iran which is contrary to building standards and detailed plans, mostly is related to the contravention of building regulations in terms of floor area rate or stories which has caused Tehran to face with greater vulnerability to natural events. Also I found out that the economic factor is the most important reason for building violations in Tehran.
\end{abstract}

Keywords: Building contravention; Municipality; Tehran metropolis; violation

\section{Introduction}

Urban management has attracted considerable institutional attention at the international level. There are some different definitions for urban management; its concept "lacks coherence, and the implications of its use are vague and contradictory" [1]. Davidson and Nientied [2] defined it as "taking an active role in developing, managing and coordinating resources to achieve a town's urban development objectives". According to Mattingly [3], it is the implementation of public administration with a specific character such as greater involvement of the private sector or taking an active role rather than just a passive role in achieving town development. Its term is combination of qualities such as physical (town) planning, project management, public administration, and business organization management. MacGill [4] stated that urban management has two objectives: "first, to plan for, provide and maintain a city's infrastructure and services, and second, to make sure that the city's government is in a fit state, organizationally and financially, to ensure that provision and maintenance". From another perspective, the urban management can be considered along with a regulated and sustainable development. In Iran, its definition has been limited to the administration of cities mainly due to the variety of structural, organizational, technical and budgetary problems. Because of these constraints, the problems in Iranian cities not only have remained unsolved, but also have wasted their existing potentials.

For development of cities and rehabilitation of urban settlements, urban management is very important and has a decisive role in developing countries like Iran. On the other hand, the informal urban districts are a huge challenge against planned and managed urban development [5]. Urban development plans include responsibility of groups and organizations, financing method, operational projects and urban construction rules and regulations are the only applicable dimensions of urban development plans [6]. The expansion of urban areas and the need for housing and development with a variety of technologies have influenced living conditions of people and have caused many of cities to face with a crisis. The increase in the number of cars, increase in the price of land and housing, the need for public services, urban health issues, the need to carry out a variety of development activities such as expansion of green space, creating or leveling asphalt pavements, public facilities, and infrastructures all require qualities in appropriate program, extensive use of specialists, meeting the needs of a city, having sufficient funds, and efficiency of urban management. Success and implementation of urban development plans is related to the quality of presenting and performing urban development rules and regulations. Urban planning and preparation of development plans in Iran is centralized, governmental, bureaucratic, and in some way affected by the rentier system. Accordingly, formal and non-formal institutions of public and private sectors, directly and indirectly have most important role and impact on the process of urban development planning.

The majority of problems in Tehran metropolitan areas are related to building contraventions, which was increased after migration from other parts of the country to the area. This migration coincided with a boom in the construction sector and an increase in density selling by the Tehran municipality due to its inefficient and inappropriate building controls. Applying non-scientific approaches in determining the density of buildings, and lack of suitability of these offers with the characteristics of residential parts, can be one of reasons that have reduced the quality of living in cities of Iran. Studies in the field of building density [7-10] reflect the impact of several factors on its determination including wintry light, open space per unit, number of residential units per area, spatial closeness, and area of building 
components all of which are important to avoid building contraventions.

There are a few national studies on assessing unauthorized urban management and building contraventions. Hadizadeh [11] stated that, in Iran, "outskirt-sitting and informal housing is rooted in structural social changes, the emergence of economic crises and accelerated migration of villagers to the cities". Rafiyan et al. [12] in their case study concluded that the sustainable development in Sabzevar city can be achieved if, firstly, residents carry out a variety of joint projects. secondly, the current urban management must change their former traditional views. Another case study analyzed the socioeconomic, spatial, skeletal, and functional effects of the illegal neighborhoods in the Chabahar city and explored the reasons that have resulted in the unauthorized urban neighborhoods in the city [13]. In one related study conducted by Sarkheyli et al. [14] to identify the reasons and origins of building contraventions in Tehran, it was revealed that developers' level of awareness is the most influential factor leading to non-compliance with floor area ratio (FAR) requirements, and housing-related motives had the greatest influence on this non-compliance. Almost no study was found that have recently assessed the building contraventions in Tehran and the Tehran municipality activities for its control. In one recent national study found in literature, Salari and Safavi Sohi [6] analyzed the status and reasons of constructional violations in Tehran. They also presented the consequences of violations which have led to the failure of urban development plans. Considering this limitation and the importance of building contraventions, in this study, using descriptive-analytical method, I attempted to analyze building regulation contraventions in Tehran and its management by Tehran municipality. First I reviewed the history of urban development rules in Iran. In next section, materials about building regulations contraventions are provided, and then, Section 3 reviews policies of building control by Tehran municipality. Finally in Section 4 conclusions and recommendations are presented.

\section{Tehran}

Tehran is the capital of Iran. With a population of around 8.4 million in the city and 15 million in the larger metropolitan area of Greater Tehran, Tehran is the most populous city in Iran and Western Asia, and has the second-largest metropolitan area in the Middle East. Tehran was first chosen as the capital of Iran by Agha Mohammad Khan of the Qajar dynasty in 1796, in order to remain within close reach of Iran's territories in the Caucasus, before being separated from Iran as a result of the Russo-Iranian Wars, and to

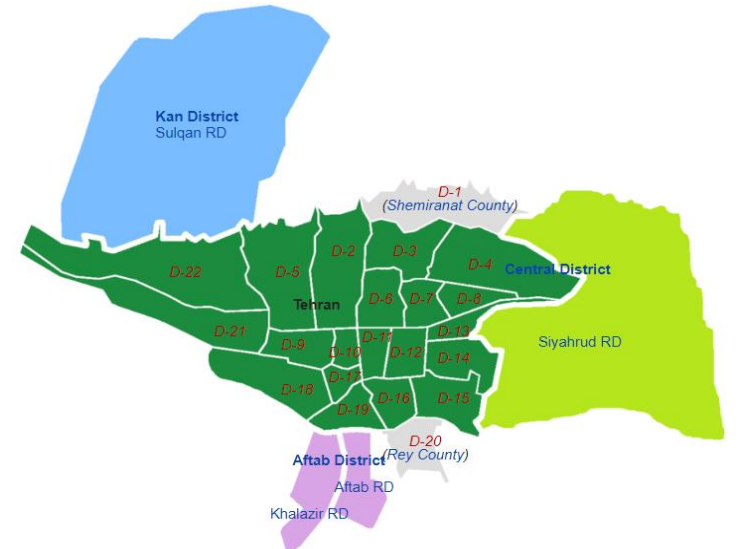

Fig. 1. Tehran's municipal divisions [from author private archive]

avoid the vying factions of the previously ruling Iranian dynasties. Large scale demolition and rebuilding began in the $1920 \mathrm{~s}$, and Tehran has been a destination for mass migrations from all over Iran since the 20th century. The metropolis of Tehran is divided into 22 municipal districts, each with its own administrative center (Fig. 1). Twenty of these districts are located in Tehran County's Central District, while the districts 1 and 20 are respectively located in the counties of Shemiranat and Ray. Northern Tehran is the wealthiest part of the city consisting of various regions.

\section{History of urban development rules in Iran}

There are three periods that can be considered as significant turning-points in the history of urbanization in Iran including two revolutions, one in 1907 that changed the type of government to Constitutional Monarchy, and the other in 1979 which led to the establishment of the Islamic Republic of Iran. The third period is related to World War II between these two revolutions. The growth and expansion of Iranian cities in the first period had almost the same characteristics as most other cities of the world and development was mainly affected by political and/or natural events. After establishment of first National Parliament (Majlis) in 1906, the first law of urban development was passed called "Baladiyeh" (municipal law) in 1907 providing a detailed outline on issues such as the role of councils within the city, the members' qualifications, the election process, and the requirements to be entitled to vote, and then two laws of Anjoman-haye Eyalati (state association), and Anjoman-haye Eyalati-va-Velayati (state/province association). After the 1907 Revolution which led to the establishment of the Pahlavi' dynasty in 1925, new legislation was passed in order to remove the legal difficulties. For example, the Municipal Law was modified in 1930. Until 1930, no other serious attempts were made for the management and control of cities. In 1937, Anjoman-haye Eyalati-va-Velayati law was changed and replaced with Administrative 
Division Law according to which Iran was subdivided into provinces (Ostan), counties (Shahrestan), districts (Bakhsh), and rural districts (Dehestan). According to this law, municipalities were as government offices under the supervision of governor. Attempts were made by the government to rehabilitate urban centers and, in particular, improve streets and urban routes. The law of construction and improvement of routes and streets was the first legal instrument in the field of municipal activity. These activities came to a halt in 1940 because of World War III. During this period, external forces created by the world economy caused fragmentation and inconsistency in the growth of the socioeconomic, spatial and political aspects of the country. There was a tendency towards modeling after Western countries blindly, without examining the suitability of those models to the country's social and physical structure, and cultural heritage. In the new town rehabilitation movement (1930-40), the old community centers turned into unstructured dispersed patterns of development. Streets which were constructed on the basis of Western cities destroyed the old boundaries of the existing districts [15, 16]. After World War II, the planning system was established in Iran and government decided to prepare socio-economic development plans, but increased oil revenue continued to facilitate dependent urbanization.

From 1944 to 1978 , in addition to the gradual modification of the laws relating to municipalities and city councils, new formal institutions and elements were entered into the urban management cycle based on the government decisions including Management and Planning Organization, Ministry of Housing and Urban Development, the League of Municipalities, and technical offices. Table 1 summaries the development plans conceived before 1979 Revolution. Mashayekhi [17] in a study has shown how the geopolitical context of the Cold War, and the political agendas of multilateral and bilateral development agencies (i.e. the World Bank and the Ford Foundation), together with the specific circumstances of the national modernization of Iran, were decisive in shaping the Iranian planning administration and the emergence of a comprehensive master planning approach from 1945 until the 1979 Islamic Revolution. After the 1979 Revolution, no efforts were made to make a new plan until 1982 due to the war with Iraq, which commenced in 1980. In 1982, government decided to prepare a new development plan but it was not approved by the National Parliament. Until the war with Iraq which was terminated in 1988, socio-economic and cultural developments were postponed due to the freezing of the country's foreign assets, a volatile international oil market, and economic sanctions. In 1988, the first Development Plan after revolution was approved which lasted five years aimed at developing infrastructure, curtailing inflation, removing a number of nontariff trade barriers, lowering income tax rates, privatizing public enterprises, reconstruction of the war zones, liberalizing the exchange system, pursuing an equal distribution of income, creating employment for the youth., etc. The second 5-year Development Plan (1994-1999) followed the policies of the first plan. In this period, the economy continued to grow at a very slow pace despite a significant rise in oil prices during the first three years of the plan. The second plan failed in the elimination of subsidies, the privatization of state-owned enterprises, and the exchange rate unification policy. It increased Iran's foreign debt. The third and final 5-year Development Plan (2000-2005) aimed at: 1) greater transparency in the macroeconomic system and regulatory frameworks; 2) budget reforms; 3) tax reforms; 4) downsizing of the government's role in economic activities and privatization of government enterprises; 5) Promotion of the private sector; 6) dismantling of monopolies and promoting of competition and; 7) establishment of a comprehensive social safety net to protect the most vulnerable groups [18]. The rapid pace of urbanization in Iran has led to new demands for jobs, housing, urban space and goods and services, the structural adjustment to the urban economy did not increase the productive capacities of the country which resulted in dependent urbanization and unbalanced growth [16].

\section{Building regulations contraventions}

Many building owners, to expand their living space, may decide to develop their property according to changing needs and their lifestyle; for example, adding a floor, terrace, extra height, equipment and other spaces such as garages, warehouses and canopies, or even encroaching on neighbor's land. According to the rules of urban construction in most cities, building development is permitted if it observes the maximum permitted building density of construction on the land, while ensuring building strength. Failure to adhere to these principles, is one of common building violations in some cities whose effects can be observed in various dimensions (economic, social, physical and environmental) and different levels (from the neighborhood to the entire city). Building contraventions can have various forms and have a variety of effects; e.g. a small building in a suburb or a luxurious building in an elegant district [20]. According to Arimah and and Adeagbo [21], the most violated aspects of building regulations are "plot coverage, setback stipulations, room size, provision of utilities, as well 
Development Plans of Iran before 1979 Revolution [16]

\begin{tabular}{|c|c|}
\hline Plans & Objectives \\
\hline $\begin{array}{c}\text { First 7-year } \\
\text { Development Plan } \\
(1949-1956)\end{array}$ & $\begin{array}{l}\text { Establishment of the Plan \& Budget Organization as well as the machinery } \\
\text { for planning. }\end{array}$ \\
\hline $\begin{array}{l}\text { Second Development } \\
\text { Plan (1957-1963) }\end{array}$ & $\begin{array}{l}\text { An increase domestic production for the national market as well as for export; } \\
\text { the development of the agricultural and industrial sectors; the discovery and } \\
\text { extraction of new mining pools and other natural resources; the improvement } \\
\text { and completion of communication facilities; public health; and any other actions } \\
\text { deemed necessary to improve the standard of living and the betterment of public } \\
\text { services. }\end{array}$ \\
\hline $\begin{array}{l}\text { The Third Development } \\
\text { Plan (1964-1968) }\end{array}$ & $\begin{array}{l}\text { The emphasis was placed on budgetary arrangements. In this regard, the Plan \& } \\
\text { Budget Organization was brought under the control of the Prime Minister's Office. } \\
\text { A simple econometric model was developed to co-ordinate public and private } \\
\text { actions as well as to ensure the necessary investments }\end{array}$ \\
\hline $\begin{array}{l}\text { The Fourth } \\
\text { Development Plan } \\
(1969-1973)\end{array}$ & $\begin{array}{l}\text { Economic growth and increase in Gross National Income; social equity and } \\
\text { a more even distribution of income; speeding up the urbanization process; } \\
\text { decreasing the dependency of the country on imports. }\end{array}$ \\
\hline $\begin{array}{l}\text { The Fifth Development } \\
\text { Plan (1974-1978) }\end{array}$ & $\begin{array}{l}\text { The promotion of improving the standard of living for all social groups of the } \\
\text { country; maintaining rapid, but continuous and balanced, economic growth; } \\
\text { increasing the income of different social groups, with special emphasis on } \\
\text { raising the standard of living of low- income families; expanding social, } \\
\text { economic, political and cultural equity more comprehensively with special } \\
\text { emphasis on the even distribution of services for different social groups; } \\
\text { improving the quality (skills) of the work force being added to the active } \\
\text { population of the country, in order to increase output and remove some of the } \\
\text { existing deficiencies; conserving, restoring and improving the eco- environment } \\
\text { and raising the standard of living of communities, in general, and of populated } \\
\text { areas in particular; developing science and technology and expanding the } \\
\text { community's creative and innovative potential; to improve the relative quality of } \\
\text { domestic production in order to promote export to international markets; the } \\
\text { maximum use of the country's foreign exchange reserves to remove domestic } \\
\text { deficiencies and cope with inflationary pressures; and to preserve and restore } \\
\text { cultural heritage. }\end{array}$ \\
\hline
\end{tabular}

as a change of use from a wholly residential use to the incorporation of home-based enterprises". They identified factors as important predictors of low level of compliance with building regulations: "the institutional context of urban development and planning regulations; the administrative machinery for physical planning implementation which does not make for inter-agency coordination; poverty of the general populace; and the disdain and apathy of the public towards formal planning institutions in the city".

The typology and severity of building contraventions varies from society to society and from country to country. Many studies conducted in different developing countries [21, 22, 26-28] have shown that the contravention of building regulations is much more problematic in developing countries and occur in the parts of cities with lower quality of life, poverty and illiteracy. Informal settlements, slums, and periphery settlements have the highest rate of contraventions [29].

\section{Building contraventions in Tehran: Factors and reasons}

The cityscape of Tehran is polarized; the northern part is inhabited by affluent citizens, and the neighborhoods there have high quality of life. However, as one travels south, the quality of life declines and the neighborhoods become inhabited by low-income people (Fig. 2). These southern neighborhoods and the informal settlements around the city have higher incidences of building contravention [30]. According to statistics from Municipality Commission under Article 100 of the Municipality Act in 2012, on average, of every 100 new units, 15 units have violated the building regulations in Tehran. Sarkheyli et al. [14] in their study presented examples of building contraventions 

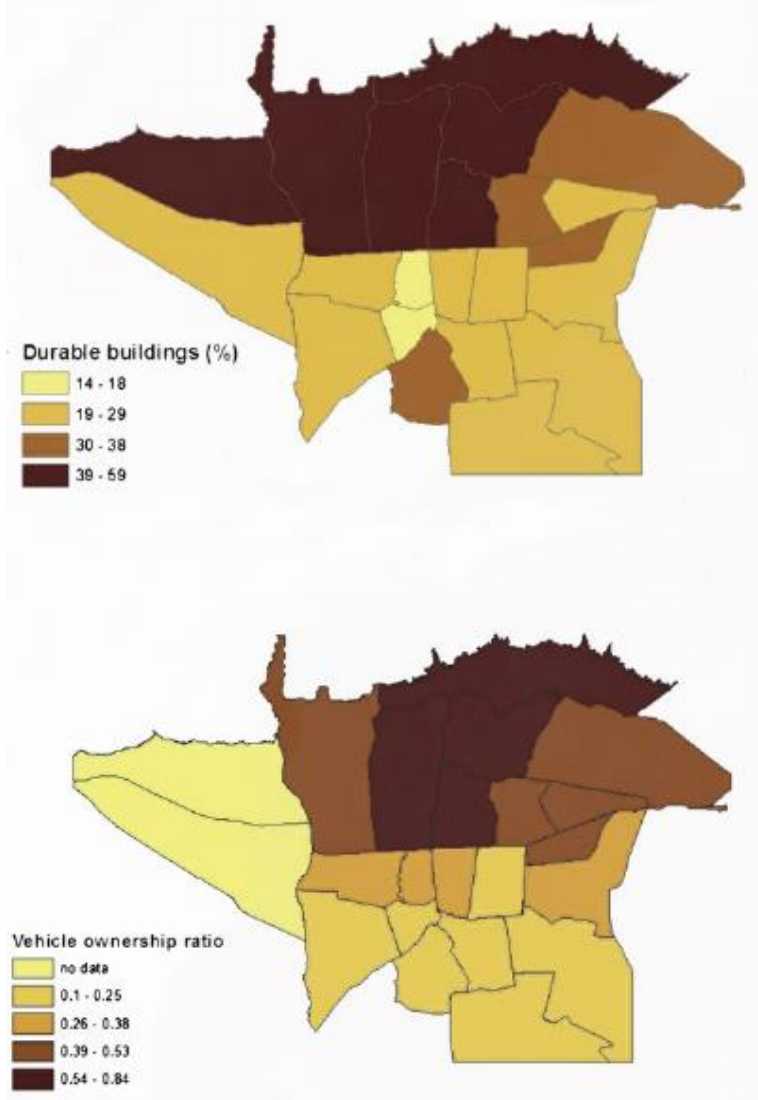
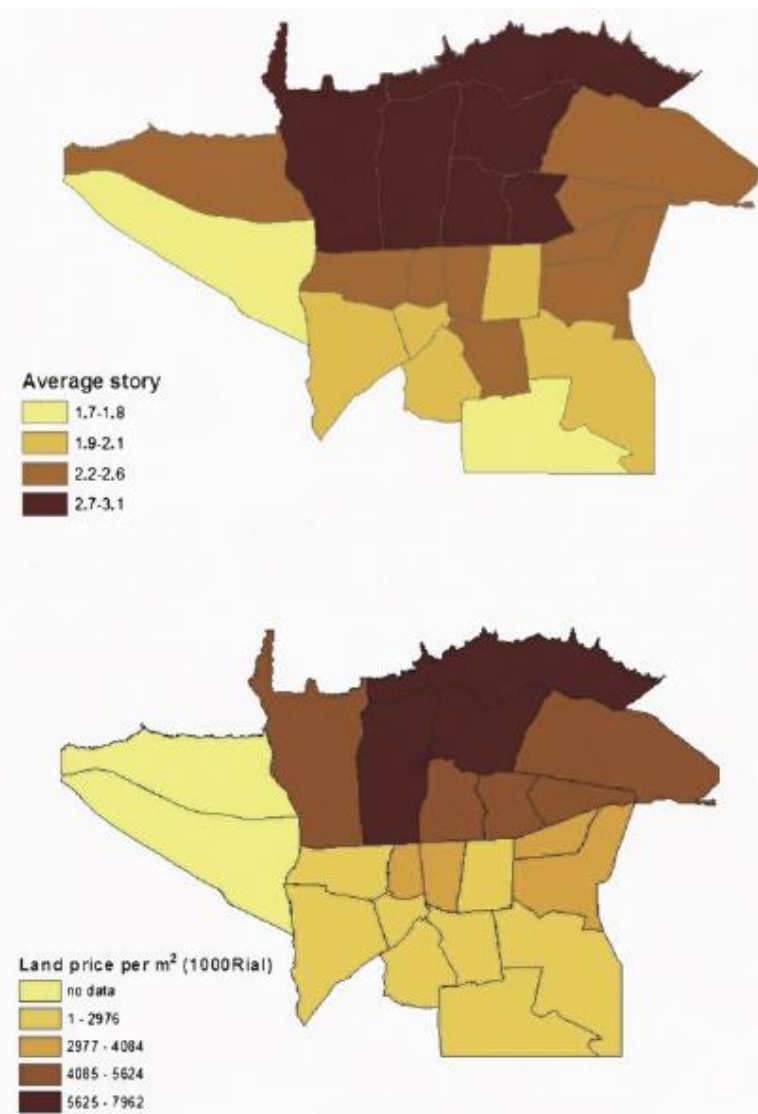

Fig. 2. Cityscape of Tehran adapted from [14]

Sarkheyli et al. [14] specified the causes and reasons

in parts of Tehran as: "illegal ownership of land, informal subdivision, unauthorized building, construction using low-quality materials, and noncompliance with floor area ratio, setback, ventilation, lot coverage, resistance-related standards and other regulations".

Building contraventions in Tehran dates back to 1945. From then on, the most common building contraventions in Iran were: Floor area contraventions, change in land use, building without permission, violation of minimum parking requirements, and violation of national building regulations. According to article 100 of national municipal act (2001), housing needs, income requirements and lack of familiarity with construction laws and regulations are the main reasons for constructional violation in Tehran [14]. In Tehran, housing construction market has become a competitive arena for those seeking maximum profit. This often led to the reduction of construction costs at the expense of the qualitative aspects of construction. Diargah [31] reported that building contravention is one of the main causes of anomalies in Tehran's urban expansion and has caused many problems such as the uneven distribution of people and activities throughout the city; the physical disorder of urban walls, edges, and spaces, which leads to a squalid visual impression (Fig. 3). for contravention of building regulations in Tehran as following: (a) Economic motives: including profitability of contravention and reducing construction costs; (b) Social motives: construction for own use; (c) Awareness level: including lack of awareness of regulations, lack of awareness of regulations' importance, and unawareness of violation; and (d) Supervision: including possibility of committing violation without the 'municipality' noticing, and protracted process of obtaining building permit. Salari and Safavi Sohi [6] argued that constructional violations in Tehran are not only the natural results of city growth and population attraction, but also the results of (a) socio-commercial conditions of Tehran, (b) weak urban management system and (c) rules and regulations which are incompatible or inappropriate with physical conditions and social and commercial requirements. In this regard, they reported wasteful migrations, residential needs, earning requirement, lack of familiarity with construction rules, people's low knowledge of planning rules and regulations, lack of appropriate financial supports for housing in addition to the increasing housing needs, having a crowded family,mistrustful of rules by people and their trivialization as the social-commercial reasons. The factors such as municipal dependency to the fines resulting from violations, lack of 


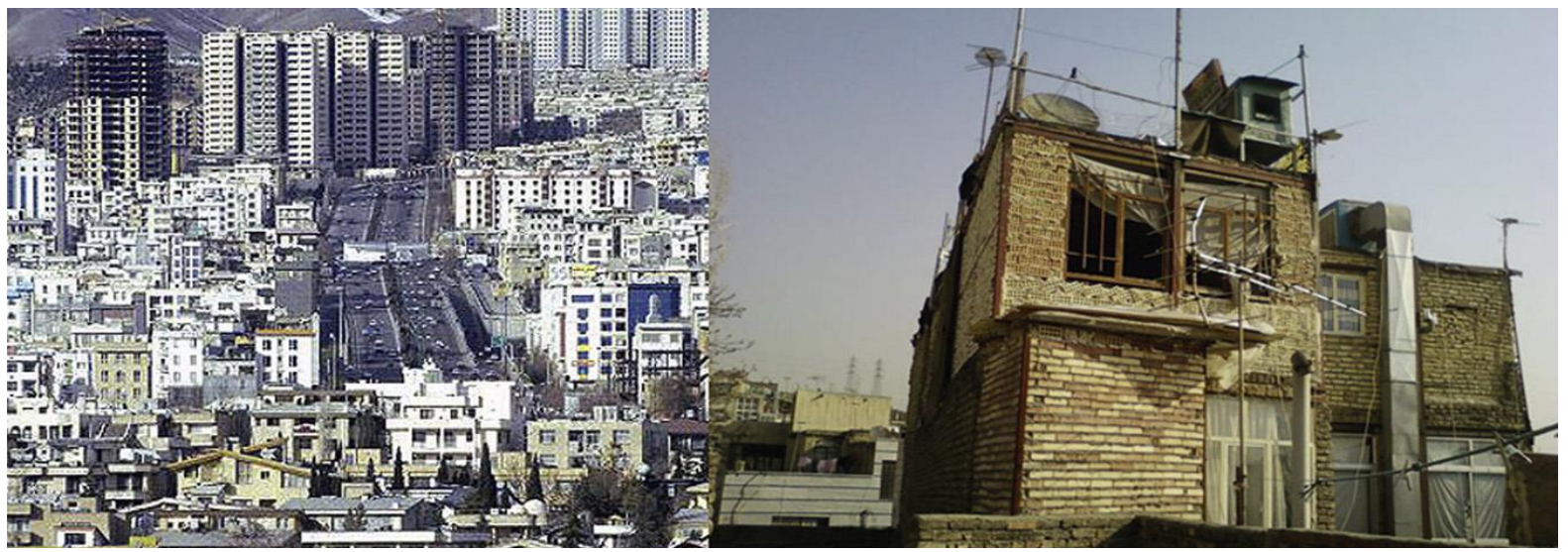

Fig. 3. An example of building regulation contravention in Tehran [14]

Consequences of building contravention in Tehran during four periods [6]

Period

1989-2001

2002-2011

2012 until now

Consequences

Marginal development and horizontal growth of Tehran; many violations of changing the usage in changing usages of green spaces and gardens (in detailed plan) and constructing unlicensed commercial unites in residential regions (these violations are the reasons of failing to fulfill large parts of approved green space and garden areas in the first comprehensive plan); wasteful constructions in the lands of Abbasabad and the lands in the west of the Kan river, constructions of co-operatives, constructions in Alborz hillside in the limits of 1800 meters, constructions in garrisons and governmental-military lands, constructions in gardens and villas in the form of garden towers and losing valuable historical or architecture textures and cultural heritage [32].

Continuing wasteful constructions until the mid-1991 and stating to consider the violations of constructing buildings without license which are related to the previous period and in this period, their existences and getting penalties were mostly accepted; the violation of having no parking (code no.10), other development rules (code no. 12), residential building with additional density (code no.2), the building contrary to the limit of permitted density (code no. 1) and changing usage (the code 6) are the major violations of this period; persuading to construct additional density and existence of constructional violations with additional density according to policies of selling density; entering large number of citizens who do not have any expertise to construction industry and constructing unstable, unsafe, without engineering methods and lack of quality buildings; high volume of violations in residential building with additional density and as a result, unpredicted increasing in population of Tehran districts including the northern districts 2, 4 and 5. Finally increasing the requests of urban facilities such as passages and infrastructures. Increasing the urban traffic which is affected by violation of residential building with additional density and changing usage; high volume of violations in changing usage in the central districts 12, 13 and 6, and southern industrial districts like 15 and 16 ; improvement and chamfer and plan which are not observed (code no.11) are the major violations of this period and its result is just destroying the opportunities of changing passages, making streets which is proposed in detailed and comprehensive plan of Tehran.

Increasing in the violations of other development rules (code no.12) and the violation of changing usage (the code 6) and also, significant increasing (nearly doubled) in the violation of changing usage in the districts 22,7 , 9 and 3. Considerable number of violations in changing usage in the districts 6 and 12 and finally intensifying the focus of non-residential activities in central districts and intensifying instability of spatial structure of Tehran; serious decreasing (more than half) in violation of constructing a building contrary to the limit of permitted density (code no.1) and significant decreasing in this violation in the districts 4, 2, 5, 15, 16, 17, 18 and 19; decreasing the violation of residential building with additional density in most of the areas and increasing it in the districts 1, 7, 8, 20 and 22 (considerable increasing in the districts 1 and 22). Consequences of large number of violations in residential building with additional density in the districts $1,4,19,20$ and 22 compared to other districts and previous period can be seen in increasing settled population and increasing the requests of facilities and infrastructures and increasing the requests of travelling.

Decreasing the violation of changing usage in central districts and increasing it in northern affluent districts of the city (the districts 2, 4, 5 and 10). Increasing the mean area of violations in changing usage, compared to previous periods. Tendencies to violations of changing coarse-grained usage and finally more consequences of increasing the requests of unpredicted travelling; increasing in the violation of non-residential building with additional density in many districts of the city. Significant increasing in non-residential building with additional density in the districts $2,4,7,10,13$ and 16; constructing stored urban lands which are proposed by detailed plan before communicating the rules of detailed plan and destroying the opportunities of flexibility in responding to services and facilities needed in different districts; decreasing in violation of residential building with additional density in all districts and significant decreasing of this violation in northern and southern districts; significant decreasing in violations of having no parking (the code 10), improvement and chamfer (code no.11), other development rules (code no.12) and violation of residential building in the limit of permitted density (code no.1). 
accountability by municipal officials and not reporting violations, delaying licensing process, lack of appropriate strategies for controlling violations, weakness in urban management for preventing the violations, lack of cooperation between sections to solve housing problems, and lack of coordination in providing a technical identity for buildings were considered as administrative and management reasons; and the factors of the reasons related to noncompliance with rules and regulations were listed as: inability to perform the rules or their incompatibility with the conditions of residents, uncertainty in planning standards and its extensive changes, high growth rate in some areas and lack of proper strategies for their control.

The most important consequences of building contravention in Tehran are summarized in Table 2 where four periods are considered: A) from 1970 to 1989 when regulations of first comprehensive plan of Tehran and financial selfsufficiency of municipal were performed; B) From 1989 to 2001 when density sales policy and modifying regulations of Tehran were carried out; C) From 2002 to 2011 when amendments were made to the planning regulations of Tehran; and D) From 2012 until now when the rules of third comprehensive plan were approved and carried out.

\section{Activities and policies of building control by Tehran municipality}

Figure and Urban management affects the occurrence of urban contraventions and their increase or decrease in two ways: The first is through the policies that are instated to control urban land, respond to the needs and demands of citizens for affordable housing, and to appropriately guide related investments $[22,33]$. The second is through the direct control of urban construction and building contraventions. It has been reported that existing formal urban planning standards and regulations have been unable to control building contraventions [23]. Issuing demolition verdicts or requiring the removal of illegal buildings, and paying monetary fines were initial policies of Tehran municipality. In fact, these fines were as sources of revenue. By 1990, without a plan to guide construction activities in the municipality, the municipality was decided for "density selling", but this decision was resulted in more contravention-related problems and it became a way for citizens to gain high profits, and as an opportunity for municipality officials to increase revenues. Table 3 presents a summary of policies and actions in Tehran to manage contravention of building regulations.
TABLE 3

A summary of actions and activities related to building density management in Tehran

\begin{tabular}{l|c}
\hline \multicolumn{1}{c|}{ Activities } & Year \\
\hline $\begin{array}{l}\text { Raising the issues of building } \\
\text { contravention and establishing }\end{array}$ & 1945 \\
regulation enforcement guarantees & \\
\hline $\begin{array}{c}\text { Definition of the municipalities' } \\
\text { laws, legal liabilities and enforcement } \\
\text { measures }\end{array}$ & 1966 \\
\hline $\begin{array}{c}\text { Approval of Tehran's first } \\
\text { comprehensive plan and establishment } \\
\text { of regulations for density, usage, set }\end{array}$ & 1970 \\
back and parking in the plan & \\
\hline $\begin{array}{c}\text { Approval of building and } \\
\text { architectural law, and providing } \\
\text { guidelines for the control and } \\
\text { supervision of building and } \\
\text { construction works }\end{array}$ & 1973 \\
\hline $\begin{array}{c}\text { Expiration of first comprehensive } \\
\text { plan, presenting density selling }\end{array}$ & \\
concept as a new source of income and \\
as a result, independence of Tehran \\
municipality
\end{tabular}

\section{Conclusion}

This study attempted to analyze the incentives and reasons for the violation of building regulations related to the density in Tehran. In this regard, we discussed factors in non-compliance with building regulations and their quality. Wrong implementation of urban planning which is contrary to the building codes and detailed plans mostly is related to the contravention of building regulations in terms of floor area rate which have faced Tehran with greater vulnerability to natural events. Buildings must comply with the limitations of the approved building density. Another issue is land use control. In land segregation for new urban areas, it is mainly focused on residential subdivision without considering space requirements for schools, parks, mosques, roads, public parking, shopping centers, pedestrian paths, open and green spaces; and in design of buildings and determining building density, landscape has small role. Most towns have remained single and centered. Economic and budget problems is such that municipality prepares the budget for required costs by density selling, issuing fines for many building violations, issuing permits for any construction even noisy ones, and disturbing the peace of residents in 
neighborhoods. In most towns with detailed and comprehensive plan, there is an attempt to change the land use which is because of the lack of experienced specialists in urban planning decisions, increased density and floor area, destruction of urban green spaces, and creating a land-use plan without paying attention to the width and area of roads and the capacity of the space available for them. In general, economic issues have received more attention rather than social issues. This has affected even the conditions of traditional urban textures. Social life is turning into personal life. Houses are destroyed due with the permission of the municipality to be converted into multi-storey buildings for sale. It is suggested that Tehran municipality should expand social sectors and consider their great role in urban management programs. In this respect all municipal and urban management programs should be based on mental and social studies and behavioral patterns of residents and their improvement.

Given the association between the knowledge of infringement related to building density and the large number of violations in this regard indicates that the majority of builders and officials have insufficient knowledge of construction rules and standards. Unfortunately, construction activities in Tehran are largely carried out by non-specialist groups for whom financial benefits are more important than quality and safety of the buildings. So, employing specialists and experienced groups for constructions in Tehran is a need and it should not be done by non-specialist ones. A large number of people have motivations to violate the construction rules in Tehran in order to meet the needs of family. This indicates a lack of response to housing policies or unsatisfactory policies for various groups of society. Thus, it is necessary to make attempts in complying rules and standards in building with social, economic and cultural conditions of people. On the other hand, it should be noted that the motivation for meeting the needs of family, in addition to social aspect, has economic aspect as well. For example, a building as a saving for the children's future, housing development for providing more living space for the family members, the construction of additional storeys for collecting money from their rent or meeting increasing household costs, and etc. all are economic incentives. Many residents after the initial awareness of many benefits of construction are entering in this industry attempting to develop the land and residential spaces. Therefore, the roots of building density violations can be property speculation, inappropriate system of employment and unfavorable distribution of income. Improving the quality of supervision on constructions, promoting law-abiding sense among the residents, the employment of specialists for constructions, making residents and groups involved in the construction aware of the consequences of building violations and the importance of construction standards, establishing training programs for constructioneers related to urban development, rating the quality of buildings (in term of sustainability, safety, design and energy consumption), managing the public investment on social and economic projects more effectively, the use of appropriate equipments to monitor and manage the growth rate of city (e.g. using smart codes), and requesting violators to compensate more decisively instead of just issuing fines can be effective in controlling these illegal and profit-based activities in Tehran as well as other cities of Iran.

\section{References}

1. Stren, R. Urban management in development assistance: An elusive concept. Cities, 1993, Vol. 10(2), p. $125-138$. https://doi.org/10.1016/0264-2751(93)90044-J

2. Davidson, F., Nientied, P. Introduction. Cities 1991, Vol. 8(2), p. 82-86. https://doi.org/10.1016/0264-2751(91)90001-8

3. Mattingly, M. Meaning of urban management. Cities, 1994. Vol. 11(3), p. 201-205. https://doi.org/10.1016/02642751(94)90060-4

4. MacGill, R. Urban management in developing countries. Cities, 1998, Vol. 15(6), p. 463-471. https://doi.org/10.1016/S0264-2751(98)00041-9

5. Hölzl, C., Nuissl, H. Urban policy and spatial planning in a globalized city - a stakeholder view of Santiago de Chile. Planning Practice \& Research, 2014, Vol. 29(1), p. 21-40. https://doi.org/10.1080/02697459.2013.872895

6. Salari, M., Safavi Sohi, M. Analyzing the role of constructional violations in the failure of urban development plans of the Tehran Metropolis. Bagh-e Nazar, 2017, Vol. 14(51), p. 5-24. http://www.sid.ir/En/Journal/ViewPaper .aspx?ID=545745

7. Oh K., Jeong Y., Lee D., Lee W., Choi J. Determining development density using the Urban Carrying-Capacity Assessment System. Landscape and Urban Planning, 2005, Vol. 73(1), p. 1-15. https://doi.org/10.1016/j. landurbplan.2004.06.002

8. Chan E.H.W., Tang B-S., Wong W-S. Density control and the quality of living space: a case study of private housing development in Hong Kong. Habitat International, 2005, Vol. 26(2), p. 159-175. https://doi.org/10.1016/S01973975(01)00041-8

9. Chen H., Beisi J. and Lau S.S.Y. Sustainable urban form for Chinese compact cities: Challenges of a rapid urbanized economy. Habitat International, 2008, Vol. 32(1), p. 28-40. https://doi.org/10.1016/j.habitatint.2007.06.005

10. Joshi K.K., Kono T. Optimization of floor area ratio regulation in a growing city. Regional Science and Urban Economics, 2009, Vol. 39(4), p. 502-51. https://doi.org/10.1016/j.regsciurbeco.2009.02.001 
11. Rafiyan, M., Momtaz, S., Shiripour, M. Advocacy Approach in Urban Planning, case study of Golestan neighborhood in Sabzevar city. Geographical and Urban Planning Research, 2014, Vol. 2(3), p. 277-331. http://dx.doi.org/10.22059 /jurbangeo.2014.53057

12. Hadizadeh, M. Global solution out ways to unauthorized settlements. Mashhad, Iran: Ferdowsi University, 2004. [In Persian]

13. Shahraki, A.A. Urban planning and design in unauthorized neighbourhoods using case studies. International Journal of Sustainable Built Environment, 2017, Vol. 6(2), p. 273-284. https://doi.org/10.1016/j.ijsbe.2016.09.005

14. Sarkheyli E., Sharifi A., Rafieian M, Bemanian M.R., Murayama A. An investigation of the reasons for noncompliance with FAR regulations in Tehran. Cities, 2012, Vol. 29(4), p. 223-233. https://doi.org/10.1016/j.cities. 2011.09.004

15. Hashemi, F. (1992) Hoghoghe-Shahri va Ghavanin-Shahri (Urban rights and Urban laws). Tehran, Iran: Centre of Iran Urban and Architecture Study and Research. [In Persian]

16. Ardeshiri, M. (1996). Urban management and urban development in Iran ( $\mathrm{PhD}$ thesis, University of South Australia). Australia. http://search.ror.unisa.edu.au/media/researcharchive/open/9916069709301831/53132979460001831

17. Mashayekhi, A. (2018) The 1968 Tehran master plan and the politics of planning development in Iran (1945-1979). Planning Perspectives. https://doi.org/10.1080/02665433.2018.1468805

18. Valadkhani, A. (2001). An Analysis of Iran's Third Five-Year Development Plan In the Post-Revolution Era (20002005). Journal of Iranian Research and Analysis, 17(2), 1-21.

19. Aguilar, S. Crime Prevention in the EU. Master thesis, University of Örebro, Sweden, 2006.

20. Kahraman, S., Saati, A., Misir, S. Effects of adding illegal storeys to structural systems. Sadhana, 2006, Vol. 31(2), p. 15-526. https://doi.org/10.1007/BF02715910

21. Arimah, C., Adeagbo, D. Compliance with urban development and planning regulations in Ibadan, Nigeria. Habitat International, 2000, Vol. 24(3), p. 279-294. https://doi.org/10.1016/S0197-3975(99)00043-0

22. Alnsour, J., Meaton, J. Factors affecting compliance with residential standards in the city of Old Salt, Jordan. Habitat International, 2009, Vol. 33(4), p. 301-309. https://doi.org/10.1016/j.habitatint.2008.08.003

23. Fekade, W. Deficits of formal urban land management and informal responses under rapid urban growth: An international perspective. Habitat International, 2000, Vol. 24(2), p. 127-150. https://doi.org/10.1016/S01973975(99)00034-X

24. Rukwaro, R. W. The owner occupier democracy and violation of building bylaws. Habitat International, 2009, Vol. 33(4), p. 485-498. https://doi.org/10.1016/j.habitatint.2009.03.004

25. Ioannidis, Ch., Psaltis, Ch., Potsiou, Ch. Towards a strategy for control of suburban informal buildings through automatic change detection. Computers, Environment and Urban Systems, 2008, Vol. 33(1), p. 64-74. https://doi.org/10.1016/j.compenvurbsys.2008.09.010

26. Few, R., Gouveia, N., Mathee, T., Harpham, A., Cohn, A., Swart, A. Informal subdivision of residential and commercial buildings in Sao Paulo and Johannesburg: Living conditions and policy implications. Habitat International, 2004, Vol. 30(1), p. 427-442. https://doi.org/10.1016/S0197-3975(03)00042-0

27. Winayanti, L., Lang, H. C. Provision of urban services in an informal settlement: A case study of Kampung Penas Tanggul, Jakarta. Habitat International, 2004, Vol. 28(1), p. 41-56. https://doi.org/10.1016/S0197-3975(02)00072-3

28. Kapoor, M., Blanc, D. Measuring risk on investment in informal (illegal) housing: Theory and evidence from Pune, India. Regional Science and Urban Economics, 2008, Vol. 38(4), p. 311-329. https://doi.org/10.1016/j. regsciurbeco.2008.03.005

29. Fernandes, E. Regularization of informal settlements in Latin America. Cambridge, USA: Lincoln Institute of Land Policy, 2011

30. Sarkheyli, E. An exploration of influence of Tehran's spatial structure on occurrence of building contraventions. Master thesis, Tarbiat Modares University, Tehran, Iran, 2010. [In Persian]

31. Diargah Architectural and Urban Planning Consultant Firm. The revision and modification of the process of building contraventions' control in Tehran. Tehran, Iran: Planning and Architecture Department of Tehran municipality, 2010. [In Persian]

32. Saeidniya, A. Autopsy of Tehran Comprehensive Plan. Shahrnegar, 2013, 59, p. 14-29. [In Persian]

33. Huchzermeyer, M. From contravention of laws to lack of rights: Redefining the problem of informal settlements in South Africa. Habitat International, 2004, 28(3), p. 333-347. https://doi.org/10.1016/S0197-3975(03)00058-4

\section{INFORMATION ABOUT AUTHOR:}

Mohammad Hossein Hajialirezalou MS in Architectural Engineering, Department of Architecture, Shabestar Branch, Islamic Azad University, Shabestar, Iran; Email address: hajialirezalou.mh@gmail.com

Kopsavilkums. Lielākā daḷ Teherānas metropoles problēmas ir saistītas ar būvniecības likumdošanas pārkāpumu veidošanos. Publikācijas pamatā ir izmantota aprakstošās analīzes metode. Apskatīti faktori, kas saistīti ar būvniecības noteikumu neievērošanu un to kvalitāti Teherānas pilsētā. N̦emot vērā pastāvošo būvniecības politiku un ar būvniecības kontroli saistīto darbību pārskatu, tiek secināts, ka nepareiza pilsētplānošanas īstenošana Irānā ir pretrunā ar pieņemtajiem standartiem un detālplānojumiem. Galvenokārt tas saistīts ar apbūves blīvuma pārkāpumiem, kas radījis urbāno slodzi uz dabas pamatni. Problemātika ir saistāma ar valsts ekonomiskās politikas jautājumu sakārtotību un to pielietojumu. 